\title{
The coming of age of AGE
}

\author{
Aubrey D. N. J. de Grey (iD
}

Received: 23 November 2020 / Accepted: 24 November 2020 / Published online: 27 November 2020

(C) American Aging Association 2020

The field of biogerontology is over a century old. It began in the wake of the stupefying advances made in the nineteenth century in understanding the basis for the infectious diseases that historically killed about $40 \%$ of babies before their first birthday - and, of course, in translating that understanding into control of such diseases. From that perspective, it was entirely logical to view the diseases and disabilities of late life as the next medical frontier, and to be optimistic about future progress. By the end of World War 2, this line of thinking had become sufficiently mainstream to warrant the formation of learned societies bringing together its leading researchers, of which the US example the Gerontological Society of America was founded in 1945. The inaugural issue of its journal, the Journal of Gerontology, was emblazoned with the slogan "Giving life to years, not just years to life"-illustrating unambiguously both the goal of biologists in this young field and also the appreciation that that goal is so often misunderstood to be about lifespan for lifespan's sake, rather than as a mere side effect of healthspan.

By the 1960s, however, and despite substantial progress, that misunderstanding was alive and kicking. What were researchers to do? Wisely or unwisely, most of them elected to pursue a path of political correctness, downplaying the dreaded side effect of life extension and focusing on aging as a phenomenon whose details might be understood but whose manipulation was a

A. D. N. J. de Grey ( $\bowtie)$

SENS Research Foundation, Mountain View, CA, USA

e-mail: aubrey@sens.org matter of science fiction. The calculus was that this was the best way to secure government funding for such work - and indeed, in the near term at least, so it proved, with the formation of the National Institute on Aging. The discussion of intervention as a goal became severely deprecated, and a few years later, when the concept of "compression of morbidity" was introduced, it was embraced with positively indecent fervor as a way to further obfuscate the situation and reassure those pursestring-holders unable to get past fears of inability to pay pensions, etc.

Only a few prominent experts held true to the field's original ideals. One, Roy Walford, became relatively well known to the general public for his promotion of calorie restriction. But the most vocal among his peers was the author of the first bona fide mechanistic theory of aging, Denham Harman. Once it became clear that he was but a voice in the GSA wilderness, he resolved to use his prestige as a safe haven for like-minded but less established colleagues, and in 1970 he created a breakaway society, the American Aging Association, to which he assigned the non-acronymic abbreviation $A G E$. That same name was given to the Association's journal - until, not too many years ago, it was changed to (you guessed it) Geroscience.

Then began a long haul. When I entered the field in the late 1990s, AGE was not a particularly wellrespected organization; prominent researchers lent it their support, but (it seemed to me) only ambivalently, and the annual meetings were not at the level seen elsewhere. But by the early 2000s, that had already begun to change, and for at least a decade the AGE 
conferences have been among the world's best meetings in the field.

The journal's change of name was not, as with the abandonment of intervention half a century ago, inspired by political self-interest. The causality was the reverse: the times ARE a-changing, and the novel term "geroscience" is being used far and wide to sound that clarion call. Its novelty is itself an asset, of course, since it is free of the connotations and baggage that beset words like "healthspan." It has thus been defined as we wish to define it: as a statement of fact and of intent. Gerontologists have finally escaped from the (somewhat self-laid) trap of political correctness that forbade them to think, let alone speak, of medical postponement of the chronic health conditions of late life. The pendulum has swung back to the attitudes that prevailed in the early decades of the field, and that is where it will stay. The emphasis on intervention in articles published in Geroscience, in my own journal [1-10], and elsewhere in the research literature is now immutable.

Harman's role in leading the science of aging is much more widely known and appreciated than his role in keeping the fire of truly bioMEDICAL gerontology burning during the years when so many had abandoned it. But I, who am sometimes absurdly touted these days as the first biogerontologist to say that aging is a tractable medical problem, never forget the giants on whose shoulders I stand-of whom Harman is, for me, the foremost. Returning to this editorial's title: coming of age is supposed to be the point at which one attains the status of adulthood. Well, in the year in which we celebrate the semicentenary of AGE's founding, I think it is fitting to propose that 50 is the new 21 .

\section{References}

1. Schwerdt JI, Lopez-Leon M, Cónsole GM, Brown OA, Morel GR, Spinedi E, et al. Rejuvenating effect of longterm insulin-like growth factor-I gene therapy in the hypothalamus of aged rats with dopaminergic dysfunction. Rejuvenation Res. 2018;21(2):102-8.

2. Nasello M, Schirò G, Crapanzano F, Balistreri CR. Stem cells and other emerging agents as innovative "drugs" in neurodegenerative diseases: benefits and limitations. Rejuvenation Res. 2018;21(2):123-40.

3. Niraula P, Ghimire S, Lee H, Kim MS. Ilex paraguariensis extends lifespan and increases an ability to resist environmental stresses in drosophila. Rejuvenation Res. 2018;21(6): 497-505.

4. Singh AK, Singh S, Tripathi VK, Bissoyi A, Garg G, Rizvi SI. Rapamycin confers neuroprotection against aginginduced oxidative stress, mitochondrial dysfunction, and neurodegeneration in old rats through activation of autophagy. Rejuvenation Res. 2019;22(1):60-70.

5. Liu CF, Li XL, Zhang ZL, Qiu L, Ding SX, Xue JX, et al. Antiaging effects of urolithin A on replicative senescent human skin fibroblasts. Rejuvenation Res. 2019;22(3): 191-200.

6. Moody KJ, Tinklepaugh J, Obert E, Grohn K, DeRosa JR, Lumen E, et al. Recombinant manganese peroxidase reduces A2E burden in age-related and Stargardt's macular degeneration models. Rejuvenation Res. 2018;21(6):560-71.

7. Mahdi A, Pernow J, Kövamees O. Arginase inhibition improves endothelial function in an age-dependent manner in healthy elderly humans. Rejuvenation Res. 2019;22(5):3859.

8. Calimport SRG, Bentley BL. Aging classified as a cause of disease in ICD-11. Rejuvenation Res. 2019;22(4):281.

9. Larrick JW, Mendelsohn AR. Roads to the fountain of youth? Rejuvenating Intestinal Stem Cells Rejuvenation Res. 2019;22(4):342-7.

10. de Grey ADNJ. TAME: a genuinely good use of 75 million dollars. Rejuvenation Res. 2019;22(5):375-6.

Publisher's note Springer Nature remains neutral with regard to jurisdictional claims in published maps and institutional affiliations. 